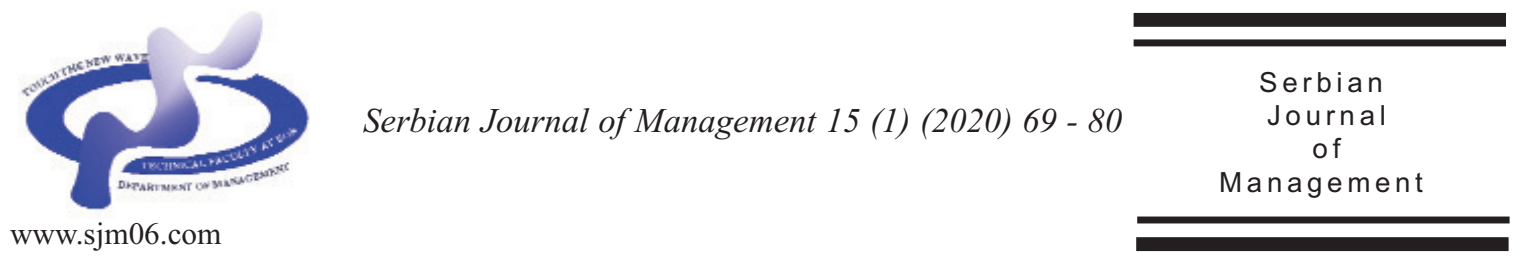

\title{
THE IMPACT OF THE RELATIONSHIP BETWEEN THE STATE, STATE INSTITUTIONS AND TAX PAYERS ON WILLINGNESS TO PAY TAX
}

\author{
Piroska Dobos ${ }^{a *}$ and Katalin Takács-György \\ ${ }^{a}$ Óbuda University, Doctoral School on Safety and Security Sciences, \\ Népszínház st. 8, 1081, Budapest, Hungary \\ bóbuda University, Faculty of Business and Management, \\ Tavaszmezö st. 15-17, 1084, Budapest, Hungary
}

(Recieved 16 May 2019; accepted 02 April 2020)

\begin{abstract}
There are several economic models in the literature that seek to correlate between human behaviour patterns, attitudes, tax evasion and its risk, also their institutional background. The values, the societal norms and attitudes differ from country to country, and these differences have a measurable effect on economic manners. Unethical business behaviour and the reasons of hidden economy are widely examined by more kinds of research methods. According to the results of many studies, we can assume that the trust in government, the stability of the tax system, and treating taxpayers as partners and with respect have positive effect on willingness to pay tax. Apart from this, direct political participation of the citizens and their involvement in political decisions and democracy have significant positive effect on tax morals as well. The aim of present study is to support these statements based on a questionnaire survey among the competent managers of small and medium-sized enterprises in Hungary and with the help of in-depth interviews - from an economic psychological perspective - with some interviewees present in several countries as taxpayers.
\end{abstract}

Keywords: willingness to pay tax, government, hidden economy, tax system, tax evasion

\section{INTRODUCTION}

In the life of the National Tax and Customs Office (NAV), a turning point was the year 2016. In 2016, the process started to make NAV a non-tax office, but a provider of services acting in a way that supports taxpayers' affairs. The aim of the transformation is to create a tax office that cooperates with customers to effectively

\footnotetext{
* Corresponding author: d.piri@globalprofit.hu
}

DOI: $10.5937 /$ sjm 15-21750 
meet the social and government expectations, by transforming the culture of administration and by creating the availability of services, taxpayers are encouraged to pay fair tax payments. For this reason, supportive procedure that helps to correct defaults and mistakes instead of immediate punishment. The rating of taxpayers has provided the opportunity to get profitable taxpayers, within the limits provided by the laws. The main goal is to operate a credible, client-centric National Taxation and Customs Administration, which is accepted by the society and at the same time improves voluntary observance and tax moral (NAV Yearbook, 2016). At the same time, serious severities were introduced, as the online cash registers from 2014, the EKÁER from 2015, the road freight monitoring system, and from July 1st, 2018, the system of online accounting programs, as a result of which, when the issuance of the invoice, the data on invoice traffic of the enterprises are transferred to the taxation authority in real time. From the measures they expect further whitening of the economy, the clearing of market, the value added tax incomes to increase and the introduction of more aimed controls. Similar systems to online invoice issuance have been already introduced in other countries as well, but for the time being only at very few places, thus, Hungary is one of the leaders with such form of digitalisation. Based on these, what can be more effective method from the authorities to whiten the economy the supportive, partner cooperation or the strictness, the forcing efforts? In the following, we would like to present some significant pieces of research on the impact of tax policy and state regulatory factors on the black economy.

\section{LITERATURE REVIEW}

Most often, one of the leading causes of the black economy is attributed to high tax burdens, but many studies have shown that tax cuts do not necessarily entail an increase in tax revenues. Tax compliance depends on many factors. Alm et al. (1995) experiments on compliance with tax rules were carried out in Spain and the United States. The two countries are very different both in culture and history. It has been found that subjects in the United States have consistently shown a higher degree of compliance than participants in the same experiments in Spain, and these differences have been attributed to compliance with higher social standards in the United States. Strümpel (1969) carried out an international comparative survey in Europe, comparing the tax systems of different European countries and the level of tax moral between taxpayers in some countries. The tax moral in Germany was relatively low, while in England it was relatively high. In his view, the main difference between the German and the English tax systems at this time was that the German government used forced tax control techniques, while the English system handled taxpayers with more respect and less control. According to Frey and Feld (2002) the tax moral of taxpayers increases when tax officials treat them with respect. In contrast, when tax officials rely solely on the deterrence of taxpayers, they tend to react by trying to actively avoid paying taxes. In addition, it has been shown that authoritarian approaches are more likely to displace tax moral and also if citizens have fewer political rights to participate. In contrast, a respectful approach and a high level of political participation by citizens greatly increase tax moral. According to Frey and 
Torgler (2006) direct political participation of taxpayers is also of great importance for willingness to pay tax, direct political participation leads to lower tax evasion and higher internal motivation for tax payment. The quality of political institutions has a noticeable impact on tax moral, political stability, non-violence, government efficiency, quality of regulation, rule of law and handling the level of corruption are also having a strong impact on tax moral. Cummings et al. (2004) say that coercive efforts can increase compliance with tax rules, but extreme punishment can even have an adverse effect - lower tax payments and loss of general confidence in state institutions. It can be seen from a comparative analysis of Botswana and South Africa - though the countries are geographically neighbours, they are very different in their social history. In South Africa, tax fraud is treated as a serious crime, while in Botswana; the tax authority's attitude is much more helpful. British colonial rules have achieved visible success in Botswana, as it has been the fastest growing economy in the world over the last 35 years. Alm et al. (2006) studied the tax attitude, tax moral or the internal motivation of citizens to pay taxes in the Russian economy at the beginning of the transition (1991) during (1995) and later (1999). The results suggest that higher levels of trust in the state have a positive effect on tax moral. Tax evasion is widespread in transition countries. The tax attitude of citizens depends on many factors. One of the main determinants of tax moral is trust in the government and in the legal institutions. In the 1990s, the Russian tax enforcement strategy was based on strong coercive methods, mainly due to an increase in mandates from law enforcement agencies.
The results of the research show that the tax moral in Russia has decreased significantly. „The importance of trust as an emotional attitude in the operation of a modern market economy is so significant that many areas and phenomena of the economy cannot be analyzed without a clear picture of the role of trust, but fraud is also an integral part of this topic, a phenomenon that is indispensable to filter out, and which - if it comes up undermines trust" (Hámori, 1998).

Kirchler et al., (2008) considers that the power of the tax authority and the appropriate size of trust in the tax authority should be understood as a means of enforced and voluntary taxation. In a hostile environment, taxpayers and tax authorities are working against each other, while in a synergistic climate they cooperate. In a hostile environment, there is likely to be a high social distance, little respect towards the authorities, so that voluntary tax payments are negligible and citizens benefit from tax avoidance. On the other hand, in the case of a ,service and customer” approach, the authorities aim to support taxpayers. For example, in Switzerland, the friendly and respectful treatment of taxpayers by tax authorities has long been recognized as an important resource for enhancing compliance with tax rules. The power of the tax authority and trust in the tax authority together affect the level of tax compliance. If the trust in public authorities is low and the power of the authorities is weak, it is likely that citizens will strive to maximize their individual results by evading taxes. Schneider and Buehn (2012) analyzed the shadow economies of 39 OECD countries with the MIMIC method between 1999 and 2010 (including Hungary). The impact of a higher shadow economy on official GDP data will result in a negative value expected 
and reduce government revenue. Tax policy and state regulatory factors also have an impact on the black economy, which, if they grow, will also increase the black economy. Schneider (2000) mentions only the high tax burden as one of the causes of the hidden economy, but there are several reasons for this, such as the impact of regulations, the complexity and transparency of the tax system, and the behaviour of taxpayers towards the state. Below, let me examine the widespread possibilities and the methods chosen by us for the measurement of the shadow economy.

\section{RESEARCH METHODOLOGY}

Measurement of the shadow economy is possible through micro-level surveys, questionnaires, interviews, observation or indirect methods such as the demand for currency or hidden variables, using macroeconomic indicators. Among the listed methods, the questionnaire survey and the interview method were chosen to measure the factors and attitudes motivating entry into the black economy - with the aim of supporting the relationships revealed on the basis of the international literature already presented. Sampling was not carried out by probability theory / expert procedure. The questionnaire was specifically aimed at the competent managers of small and mediumsized enterprises of different sizes and activities in Hungary. The topic of the survey is, among other things, the impact of demographic factors on tax moral, the impact of tax increases, tax cuts, the impact of tax simplification and the role of correct information, the impact of national pride, friendly and respectful treatment of taxpayers, their treatment as partners, citizens. It examined the impact of direct political involvement, involvement in political decision-making, democracy and the effect of self-esteem on tax moral. The questions asked in the questionnaire were closed questions, we offered pre-defined answers, and the participants had to choose the appropriate one for them. The questionnaire was available online in the autumn of 2018, with a total of 345 responses. The first part of the questionnaire includes questions about the weight and components of the hidden economy. Such questions were asked by respondents as how often invoice-free sales, the employment of unreported employees, the purchase of fictitious expense accounts, or the accounting of personal consumption as a cost among the costs of the business occur - both among business partners and competitors, also in the Hungarian economy - and how these phenomena are judged. In the second part we examined the relationship of the taxpayer with the government, the legal institutions and the control bodies, and their impact on the willingness to pay taxes. In this section we also touched on the effect of national pride on tax moral. The questions are from Semjén and Tóth (2004) and Balogh et al. (2014), based on previous studies, supplemented by own edited questions. The third part contains the questions of Rosenberg's self-esteem scale (Rosenberg, 1965; 1989), and the fourth part deals with demographic data. The present study examines the impact of the relationship between the state, state institutions and taxpayers on the willingness to pay taxes based on the 1-2. sections of the questionnaire. In addition, the questions were interviewed in the form of a ,snowball" sampling procedure for 10 respondents, thus providing an opportunity to further explore the topic. 


\section{OBJECTIVES OF THE STUDY}

Our aim - beyond the microeconomic analysis of tax evasion - is to approach taxpayers' willingness to pay taxes from a behavioural point of view, to examine the reasons leading to the decisions of individuals to tax evasion and the means by which the degree of hidden economy can be reduced. In this paper, based on the analysis of international literature, the evaluation of the questionnaire, and the summary of the interviews, we are looking for the answer to the question of how the trust in the government, the stability of the tax system and the treatment of taxpayers as partners from tax authorities affect tax avoidance and tax evasion. Based on the analysis, we expect that citizens have a higher level of confidence in government, tax administrations and other legal institutions, friendly and respectful treatment of taxpayers, their treatment as partners and direct political participation of citizens, involvement in political decisions, democracy also have a significant positive impact on tax moral. Our hypotheses are compared with the research conducted by the researchers dealing with the topic, the results of the questionnaire and the interviews, taking into account the most important international research results and synthesizing the obtained results.

\section{RESULTS}

In the online questionnaire consisting of 49 questions, 345 responses were received, 2 were excluded from the analysis due to incorrect answers. The dimensions of the large number of data sets have been reduced by main component analysis to the extent possible to keep the variance present. Based on the Bartlett test and the Kaiser-MeyerOlkin (KMO) criteria, we investigated whether the data is suitable for the main component analysis and further worked with these main components (Table 1.).

With the aim of supporting international research results, with Pearson's correlation study we looked at whether there was a significant correlation between different variables.

We can deny the null hypothesis according to the significance level (sig $=0.000<0.05)$ of the "Moral Dilemma" (F1.1). The alternative $\left(\mathrm{H}_{1}\right)$ hypothesis is fulfilled, there is a significant correlation between the variables. Based on the correlation coefficient $\left(r=-0.236^{* *}\right)$, there is a negative relationship between the "Moral

Table 1. Name of the main components

\begin{tabular}{ll}
\hline Sign & Title \\
\hline F1.1 & Moral dilemma \\
F1.2 & The relationship of the business partners and competitors with the black economy \\
F1.3 & Tax evasion in the Hungarian economy \\
F1.4 & Effect of correct information and development of the culture of taxation \\
F1.5 & Personal consumption, as company expense \\
F1.6 & Buying a fictitious cost invoice \\
F1.7 & Means of increasing willingness to pay tax \\
F1.8 & The impact of the black economy on the competitive position of other companies \\
F2.1 & The relationship between citizens and the government \\
F2.2 & The relationship between taxpayers and tax authorities \\
F2.3 & The effect of the tax system \\
\hline
\end{tabular}


Dilemma" (F1.1) and „Relationship between citizens and Government" (F2.1), which means that if the value of one indicator increases, it also entails a decrease in the other indicator. Regarding the order of the answers to the questions, it can be stated that the better the relationship between the citizens and the government, the more possibly the respondents feel that the activities related to the hidden economy are tax evasion. The less good the relationship between citizens and government is, the more possibly the respondents feel that the activities related to the hidden economy are not tax evasion.

According to the significance level of the "Tax evasion in the Hungarian economy" (F1.3) $($ sig $=0.000<0.05)$, the null hypothesis can also be rejected, so the alternative $\left(\mathrm{H}_{1}\right)$ hypothesis is fulfilled, i.e. there is a significant correlation between the variables. Based on the correlation coefficient $(r=0.267 * *)$, there is a weak positive relationship between „Tax evasion in the Hungarian economy" (F1.3) and "Relationship between the citizens and the government" (F2.1) if the value of one indicator increases, it also increases the other indicator. In terms of the order of the answers to the questions, the less good the relationship between the citizens and the government, the more secure the activities of the hidden economy are present in the economy. The better the relationship between citizens and the government, the more secure the activities of the hidden economy are less present in the economy.

The significance level $($ sig $=0.001<0.05)$ of the „Personal consumption, as company expense" (F1.5) can also be rejected by the null hypothesis. The alternative $\left(\mathrm{H}_{1}\right)$ hypothesis is fulfilled, so there is a significant correlation between the variables. The correlation coefficient $(r=0.178 * *)$ means that there is a weak positive relationship between „Personal consumption, as company expense" (F1.5) and ,Relationship between citizens and the government" (F2.1) (Table 2.). The higher the trust of citizens towards the government, the less of this form of tax evasion in the economy is present.

"The relationship of the business partners and competitors with the black economy" (F1.2) has a significance level $($ sig $=0.044<0.05)$. The alternative $(\mathrm{H} 1)$ hypothesis is fulfilled, there is a significant correlation between the variables. According to the correlation coefficient $(r=0.109 *)$, there is a weak positive relationship between the relationship of the business partners and competitors with the black economy (F1.2) and the relationship between taxpayers and tax authorities (F2.2).

Table 2. F1. Tax evasion and F2.1 the relationship between citizens and the government

\begin{tabular}{lclc}
\hline & Pearson Correlation & Sig. & Hypothesis \\
\hline F1.1 & $-.236^{* * *}$ & .000 & $\mathbf{H}_{\mathbf{1}}$ \\
F1.2 & 0.022 & .689 & $\mathbf{H}_{\mathbf{0}}$ \\
F1.3 & $.267^{* *}$ & .000 & $\mathbf{H}_{\mathbf{1}}$ \\
F1.4 & -0.091 & .093 & $\mathbf{H}_{\mathbf{0}}$ \\
F1.5 & $.178^{* *}$ & .001 & $\mathbf{H}_{\mathbf{1}}$ \\
F1.6 & 0.084 & .119 & $\mathbf{H}_{\mathbf{0}}$ \\
F1.7 & -0.069 & .205 & $\mathbf{H}_{\mathbf{0}}$ \\
F1.8 & 0.064 & .235 & $\mathbf{H}_{\mathbf{0}}$ \\
\hline
\end{tabular}

** Correlation is significant at the 0.01 level (2-tailed).

* Correlation is significant at the 0.05 level (2-tailed). 
The level of significance of ,Tax evasion in the Hungarian economy" (F1.3) is $(\operatorname{sig}=0.032<0.05)$, so the null hypothesis can also be rejected. The alternative $\left(\mathrm{H}_{1}\right)$ hypothesis is fulfilled, so there is a significant correlation between the variables $\left(r=0,116^{*}\right)$, there is a weak positive relationship between ,Tax evasion in the Hungarian economy" (F1.3) and "Relationship between taxpayers and tax authorities" (F2.2).

According to the significance level of the "Personal consumption as company expense" (F1.5) $($ sig $=0.031<0.05)$, the null hypothesis can also be rejected. So the alternative $\left(\mathrm{H}_{1}\right)$ hypothesis is fulfilled, there is a significant correlation between the variables. The correlation coefficient $\left(r=0.116^{*}\right)$ means that there is a positive relationship between „Personal consumption as a company expense" (F1.5) and „Relationship between taxpayers and tax authorities" (F2.2) (Table 3.). On the basis of the above, we can state that good relations between treating taxpayers as partners, with respect, and the relationship between taxpayers and the tax authorities have a positive effect on the willingness to pay taxes.

Analyzing the relationship between the „Effect of the tax system" (F2.3) and the tax moral (F1) - that is tax legislation is extremely complicated and difficult to navigate, and that most forms of taxation are difficult to understand - ,The impact of the black economy on the competitive position of other companies" ( F1.8) according to the significance level $($ sig $=0.017<0.05)$ the null hypothesis can be rejected. The alternative $\left(\mathrm{H}_{1}\right)$ hypothesis is fulfilled, there is a significant correlation between the variables. Based on the correlation coefficient ( $r=-$ $\left.0.128^{*}\right)$, the impact of the black economy on the competitive position of other companies (F1.8) and the „Effect of the tax system” (F2.3) is weakly negative, that is, the complexity of the tax system affects the willingness to pay tax negatively.

In order to further explore the topic, the studies were supplemented with a survey based on an interview method. The subjects of individual, semi-structured deep interviews were competent leaders in tax matters. We have sought to select interviewees who are present in other countries as taxpayers outside of Hungary, so they can provide a greater insight into taxation and the black economy in an international context as well. The interviewees included a taxpayer who was also a taxpayer in Serbia, Austria, Germany, Italy, Syria, Turkey, Australia and Switzerland. The interviews confirmed our assumption that the willingness to pay taxes

Table 3. F1. Tax evasion and F2.2 the relationship between taxpayers and tax authorities

\begin{tabular}{lccc}
\hline & Pearson Correlation & Sig. & Hypothesis \\
\hline F1.1 & -.017 & .758 & $\mathbf{H}_{\mathbf{0}}$ \\
F1.2 & $.109^{*}$ & .044 & $\mathbf{H}_{\mathbf{1}}$ \\
F1.3 & $.116^{*}$ & .032 & $\mathbf{H}_{\mathbf{1}}$ \\
F1.4 & -.081 & .132 & $\mathbf{H}_{\mathbf{0}}$ \\
F1.5 & $.116^{*}$ & .031 & $\mathbf{H}_{\mathbf{1}}$ \\
F1.6 & .065 & .232 & $\mathbf{H}_{\mathbf{0}}$ \\
F1.7 & .059 & .273 & $\mathbf{H}_{\mathbf{0}}$ \\
F1.8 & .040 & .465 & $\mathbf{H}_{\mathbf{0}}$ \\
\hline
\end{tabular}

** Correlation is significant at the 0.01 level (2-tailed).

* Correlation is significant at the 0.05 level (2-tailed). 
Table 4. F1. Connection between tax evasion and F2.3 the effect of tax system

\begin{tabular}{lccc}
\hline & Pearson Correlation & Sig. & Hypothesis \\
\hline F1.1 & -.034 & .530 & $\mathbf{H}_{\mathbf{0}}$ \\
F1.2 & .066 & .220 & $\mathbf{H}_{\mathbf{0}}$ \\
F1.3 & -.016 & .773 & $\mathbf{H}_{\mathbf{0}}$ \\
F1.4 & -.022 & .681 & $\mathbf{H}_{\mathbf{0}}$ \\
F1.5 & .027 & .612 & $\mathbf{H}_{\mathbf{0}}$ \\
F1.6 & .061 & .257 & $\mathbf{H}_{\mathbf{0}}$ \\
F1.7 & $-.285^{* *}$ & .000 & $\mathbf{H}_{\mathbf{1}}$ \\
F1.8 & $-.128^{*}$ & .017 & $\mathbf{H}_{\mathbf{1}}$ \\
\hline$* *$ Correlation is significant at the 0.01 level (2-tailed). & & \\
* Correlation is significant at the 0.05 level (2-tailed).
\end{tabular}

is influenced by the quality of the relationship between government and taxpayers, the direct involvement of citizens, involvement in political decisions, democracy and cooperation with taxpayers, and their treatment as partners.

It was present in many interviews that during authority administration, control the participants experienced an aggressive action from the authorities. „We go to a control with fear of a person who is professionally not even surely competent in the case. Still, they are keeping demonstrating their power, and they are not there to help me." Similar statements were made in another interview in connection with the question of competencies and cooperation with the authority, according to which, ,any time I spoke to a colleague of the tax authority, his competence was rather below level, and he did not even have a clue about what he should have informed me on."

„In Hungary, they are not negotiating with people as equal parties. This may be because the task is beyond their competence, so they also show that they are strong, but they have no idea what to answer."

„During one of my official administrations, the clerk told me that this was too complicated for him. Together with another colleague they asked me what to fill out on the form. They didn't understand their task. Finally, they were mistaken and caused a disadvantage to me, and even a fine was imposed on me. Two agents gave opposite information. In Switzerland, this is not the case, the clerks know what their job is."

"In Hungary the main problem is that authorities look at clients as enemies."

„I never trusted the government and the actions of the authorities when I lived in Hungary. I did not feel that they were for me and that they wanted to help me. The ATO here is not a communication champion (Australia), but here the corruption is unimaginably smaller. Sure, it's impossible to avoid, but it's not that much in the foreground. In Australia, there is no scoffing, no condescension, but polite good faith."

„The authority in Austria is unambiguously helpful. If I have a problem, then they are qualified in the topic and are able to tell the solution, they really help. It is possible that the regulations in Austria are not much simpler, but they provide you with necessary help, it can be either in written form or personally from a colleague who helps you."

„In Austria, no immediate penalty is imposed on late tax payments, but first the taxpayer is asked why he has not paid. You may have forgotten or missed the deadline, and you can even say that I'm sorry, I pay. Or even you may not know it right now, and 
then you won't be hit by the main shot, but you agree on a deadline and you will pay. If they see the company as fair and working, they are more flexible and much more helpful."

„In Austria, I have a business that has been in operation for 30 years, I run with a friend, he is the executive, it is not a big company, but not a small one either. There has never ever been an aggressive tax audit."

„We are also working with small businesses in Germany and we have never heard of tax authorities occupying them because of tax controls. Yes, people still pay taxes. I think if I get a trust, I will give that confidence back."

„There may be better tax moral in Austria because there is better cooperation between authorities and taxpayers, and we are rather partners, not a strict, hostile climate is present as in Hungary."

„Unfortunately, intimidating, punitive measures are common in Hungary. I did not experience this in Austria. The problem is that they act here against the taxpayer by assuming they are gangsters. In Hungary, authorities consider man to be an enemy. They are talking to him during an official administration as if he was a criminal. In contrast, in Austria, they appear as a service organization that helps me to solve my problem politely and quickly. Well, this is a huge difference."

„Syria is a very developed country, we lived there for three years. There everyone is normal and smiling. There may not be anything to eat for the poor, yet he is still friendly, there is temperament there, and this is also the case during official administration."

In addition to what has been said, it has also been said that not only is Hungary subjected to excessive rigor with the taxpayer. „There is also a growing rigor in Italy because of the high rate of tax evasions in recent years. If an item cannot be verified by invoice on the person's account, it is confiscated. But even if it is a used washing machine, because you move from one apartment to another and you can't prove where it is from."

It has also been said in relation to Serbia that, unfortunately, there is no characteristic that the tax authority informs companies in a timely and well-informed manner about taxrelated matters, or that they would apply friendly and respectful treatment to taxpayers, treat them as partners, and that there is no direct political participation of citizens, or involvement in political decisions, neither democracy.

„The Turkish-Hungarian authorities may shake hands with each other in recent years. There is only cornering, coercion, and punishment."

„There is weak and cheap manpower in the tax office, they are not qualified to what they are doing. Qualified professionals all work in private companies. The multinationals have the knowledge that the authorities cannot even dream of."

„In Switzerland, on the other hand, people are willing to pay tax because they know exactly what it is used for, accurate accounting, very strict conditions apply. I know what they spend the tax money on. In Switzerland, the direct involvement of citizens in political decision-making takes place, we vote there, there are more parties who control each other."

„In principle, society works by the normal citizen paying the tax, and the state maintains the system, and then there is a normal tax moral. Where politics is such, (I could tell countries - in northern countries this is usually the case, in many countries, 
the situation is much better than with us) where these money is accounted with fairly, people prefer to pay taxes."

\section{CONCLUSIONS}

Despite the fact that the tax policy of deterrence is the most common method in order to the enforcement of tax payments and regulations - that is the envisage as high punishment and fine items as possible, it might even exert the opposite effect from taxpayers. Coercion and extreme high taxes and penalties can result in lower tax payments and a general loss of trust in public institutions. It is definitely worth noting that the US tax moral surpasses all countries, because tax moral is more effective in the case of better treatment with taxpayers and in the case of forced intervention by public authorities. In addition, the high tax moral in the United States and Switzerland may mean that tax moral can be increased with the help of increasing democratic elements. In a comparative study of the English and German tax systems, we found that in Germany there was a lower tax moral than in England. The difference may also be due to the specificities of the two tax systems, while in Germany the tax control techniques were typical, while in England, respectful treatment of taxpayers. In experiential studies on the subject of deterrence and mood, we also find that the tax moral of taxpayers increases as officials respect them, while deterrence leads to tax evasion. The quality of political institutions, the stability of the tax system, non-violence have a strong impact on tax moral, and direct political participation also leads to higher internal motivation to pay tax. Higher trust in the state has a positive effect on tax moral, while tax enforcement based on heavily constrained methods reduces willingness to pay tax. If the authorities have low trust and respect, it will lead to tax evasion. In contrast, Switzerland's example is where friendly and respectful treatment by the authorities is an important resource for enhancing compliance with tax legislation. It can therefore be concluded that tax policy and state regulatory factors have a significant impact on the shadow economy.

\section{FUTURE RESEARCH PLANS}

In a further stage of the research we have involved the extent of the self-esteem of the taxpayers into the analysis, with the help of the Rosenberg self-esteem scale which is applied in international pieces of research seeking the answer to the question if the extent of the self-esteem of the individual can or cannot have effect on the involvement into the hidden economy. Several interactions can be detected between money and self-esteem, for instance, the excellent possibility of payment increases the extent of self-esteem, or the money and the selfesteem can, partially, compensate each other, but they can even compete with each other, if the decision makers have to make a choice between them. Many studies seek to find correlation between low self-esteem and the higher risk of committing crime as well. We suppose, based on the results of these examinations, which - if we consider tax refusal, tax denial, tax evasion a kind of opportunity to gain money - to the pattern of relationships between money and selfesteem, the willingness to pay tax and selfesteem have direct relationship as well. During the research we examined the direct relationship between self-esteem and tax 
moral based on this assumption. The to pay taxes (in Hungarian). Regional and research results have justified our Business Studies, 6 (1), 65-74 assumption, according to which, the extent of the self-esteem have a positive effect on tax moral. In this research however, we only achieved a momentary insight in connection with the effect of self-esteem exerted on the willingness to pay tax. Thus, in the following, we would definitely like to examine this territory with choosing other target groups also, or by the means of other methods of sampling. The research did not have the aim of discovering the extent of self-esteem between men and women, but the result is that the negative average self image of women falls into positive range on the examined sample, that is to say, women have lower self-esteem than men, and this projects ahead further possible directions of research. The female roles which have been formed in the centuries, the value of women within the family, their place in marriage and the expectations towards them within the society are clearly reflected in the research. In addition to the topic of tax evasion we would like to examine the effect of selfesteem in other topics affecting businesses, such as the corporate success.

\section{References}

Alm, J., Martinez-Vazquez, J., \& Torgler, B. (2006). Russian attitudes toward paying taxes - Before, during, and after transition. International Journal of Social Economics, 33(12), 832-857.

Alm, J., Sanchez, I., \& de Juan, A. (1995). Economic and noneconomic factors in tax compliance, Kyklos, 48 (1), 3-18.

Balogh, L., Gál, V., \& Kovács K. (2014). The willingness of the Hungarian population

Cummings, R.G., Martinez-Vazquez, J., Mckee, M., \& Torgler, B. (2004). Effects of Culture on Tax Compliance: A Cross Check of Experimental and Survey Evidence. CREMA, Working Paper No. 2004. Retrieved from http://ww.w.cremaresearch.ch/papers/2004-13.pdf.

Frey, B.S., \& Feld, L.P. (2002). Deterrence and Moral in Taxation: An Empirical Analysis. CESifo Working paper No. 760, Retrieved from https://www.ifo.de/DocDL/760.pdf

Frey, B.S., \& Torgler, B. (2006). Tax Moral and Conditional Cooperation. Journal of Comparative Economics, 35 (1), 136-159.

Hámori, B. (1998). Emotional Economics (in Hungarian), Kossuth Publishing House, Budapest, Hungary.

Kirchler, E., Hoelzl, E., \& Wahl, I. (2008). Enforced versus voluntary tax compliance: The ,slippery slope" framework. Journal of Economic Psychology, 29 (2), 210-225.

NAV YEARBOOK (2016). Facts, information on the organization of the National Tax and Customs Office and its activities in 2016 (in Hungarian). Budapest, Hungary. Retrived from http://nav.gov.hu/data/cms436895/NAV_evk onyv_2016.pdf

Rosenberg, M. (1965). Society and Adolescent Self-image. Princeton University Press, Princeton, N.J.

Rosenberg, M. (1989). Society and the Adolescent Self-image (Rev. ed.). Wesleyan University Press, Middletown, CT.

Schneider, F. (2000). The Increase of the Size of the Shadow Economy of 18 OECD countries: Some Preliminary Explanations. Working Paper, No. 0008. Johannes Kepler University of Linz, Department of Economics, Linz. Retrieved from 


\section{УТИЦАЈ ОДНОСА ИЗМЕБУ ДРЖАВЕ, ДРЖАВНИХ ИНСТИТУЦИЈА И ПОРЕСКИХ ОБВЕЗНИКА НА СПРЕМНОСТ ПЛАһАЫА ПОРЕЗА}

\section{Piroska Dobos, Katalin Takács-György}

Извод

Постоји неколико економских модела у литератури који траже корелације између људског понашања, ставова, утаје пореза и његових ризика, и њихове институционалне позадине. Вредности, друштвене норме и ставови варирају од земље до земље, а те разлике имају мерљив утицај на економско понашање. Неетичко пословно понашање и узроци скривене економије, широко се истражују различитим истраживачким методама. На основу резултата многих студија, можемо претпоставити да поверење у владу, стабилност пореског система и третман порезких обвезника, као партнера и њихово поштовање, позитивно утичу на спремност плаћања пореза. Поред тога, директно политичко учешће грађана, њихово учешће у политичким одлукама и демократија, такође имају значајан позитиван утицај на порески морал. Сврха овог рада је да подржи ове тврдње на основу упитника који су спровели компетентни руководиоци малих и средњих предузећа у Мађарској уз помоћ дубинских интервјуа, са економско - психолошке тачке гледишта, уз учешће испитаника који су као порески обвезници присутни у неколико земаља.

Кључне речи: спремност на плаћање пореза, влада, скривена економија, порески систем, утаја пореза

http://www.econstor.eu/bitstream/10419/733

24/1/wp0008.pdf

Schneider, F., \& Buehn, A. (2012). Shadow Economies in highly developed OECD countries: What are the driving forces?, IZA Discussion Papers, No. 6891, Institute for the Study of Labor (IZA), Bonn.

Retrieved from: http://www.econstor.eu/bitstream/10419/671 70/1/727543865.pdf

Semjén, A., \& Tóth, I.J. (2004). Analyzes of the Hidden Economy in Hungary, Study 4, Hidden Economy and Tax Conduct (in Hungarian), MTA Research Center for Economic Sciences, Budapest, Hungary.

Strümpel, B. (1969). The Contribution of Survey Research to Public Finance. In A.T. Peacock (ed.), Quantitative Analysis in Public Finance,14-32. New York, NY: Praeger Publishers. 